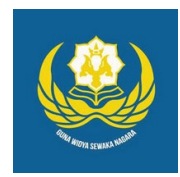

Jurnal Analogi Hukum

Journal Homepage: https://ejournal.warmadewa.ac.id/index.php/analogihukum

\title{
Pewarisan Hak Atas Tanah Yang Dibebankan Hak Tanggungan
}

\author{
Ni Komang Evic Triani*, I Ketut Sukadana dan Luh Putu Suryani \\ Universitas Warmadewa, Denpasar-Bali, Indonesia \\ *evictri@yahoo.com
}

How To Cite:

Triani, N, K, E., Sukadana, I, K., Suryani, L, P. (2021). Pewarisan Hak Atas Tanah Yang Dibebankan Hak Tanggungan. Jurnal Analogi Hukum. 3 (1). 52-56. Doi: https://doi.org/10.22225/ah.3.1.3032.52-56

\begin{abstract}
Land ownership is the highest land rights in any country. Property Right apart from being transferred can also be borne by mortgages or used as collateral for debt repayment.Land ownership has economic value for human needs. Apart from being transferred, Land ownership can also be borne by mortgages or pledged as collateral for repayment of debt. Land ownership can be transferred because inheritance of acquired land and inheritance is important to be registered to obtain legal certainty. The formulation of the problem raised in this study is; (1) What is the process of inheritance of land rights imposed with Mortgage Rights? and (2) What are the consequences faced by creditors for the inheritance of rights to land that are charged with Mortgage rights? This study aims to determine the process of inheritance of land rights that are charged with Mortgage Rights. This normative study with a method of approaching the problem of legislation with a conceptual approach. Based on the results of this study can be concluded that the process of transferring land rights due to inheritance occurs because of law. Heirs have to pay all debts left by the heir. The consequences faced by creditors are to wait for the process of returning the name of the object to the mortgage. A certificate issued by a land office has the same legal force as a court decision.
\end{abstract}

Keywords: Consequence of law; inheritance; mortgage rights

Abstrak - Tanah hak milik adalah hak atas tanah yang paling tinggi statusnya di negara manapun. Tanah hak milik mempunyai nilai ekonomis bagi kebutuhan manusia. Tanah hak milik selain dapat dialihkan juga dapat dibebankan hak tanggungan atau dijadikan jaminan dalam pelunasan hutang. Tanah hak milik dapat beralih karena pewarisan. Tanah yang diperoleh dari warisan penting untuk didaftarkan unuk mendapatkan jaminan kepastian hukum. Rumusan masalah yang diangkat dalam penelitian ini adalah (1) Bagaimana proses pewarisan hak atas tanah yang dibebankan hak tanggungan? dan (2) Bagaimana akibat yang dihadapi oleh kreditur terhadap pewarisan hak atas tanah yang dibebankan hak tanggungan? Penelitian ini bertujuan untuk mengetahui proses pewarisan hak atas tanah yang dibebankan hak tanggungan. Dalam penelitian ini menggunakan penelitian normative dengan metode pendekatan masalah perundang-undangan dengan pendekatan konseptual. Berdasarkan hasil penelitian ini dapat disimpulkan bahwa proses peralihan hak atas tanah karena pewarisan terjadi karena hukum. Hak tanggungan tidak akan hapus apabila hak atas tanah beralih karena pewarisan. Ahli waris wajib membayar semua hutang yang ditinggalkan pewaris. Akibat yang dihadapi kreditur yakni harus menunggu proses balik nama objek atas hak tanggungan tersebut. Sertifikat yang dikeluarkan kantor pertanahan mempunyai kekuatan hukum sama dengan putusan pengadilan.

Kata Kunci: Akibat hukum; pewarisan; hak tanggungan

\section{Pendahuluan}

Tanah merupakan kebutuhan pokok yang sangat dibutuhkan bagi kehidupan seluruh manusia, karena tanah merupakan salah satu unsur utama bagi kelangsungan hidup dan kehidupan manusia sepanjang masa, dengan tujuannya adalah dipergunakan untuk tercapainya kemakmuran bagi seluruh rakyat yang terbagi secara merata baik secara materil maupun spritual (Novita, 2014). Kebutuhan akan tanah dewasa ini meningkat sejalan dengan bertambahnya jumlah penduduk dan meningkatnya kebutuhan lain yang berkaitan dengan tanah (Hasanah, 2012). Kehidupan manusia tidak dapat lepas dari tanah, karena setiap dari kebutuhan manusia berkaitan dengan tanah mulai dari tempat tinggal, tempat 
beribadah, tempat bekerja dan lain sebagaiannya. Tanah juga mempunyai nilai ekonomis bagi kehidupan manusia. Tanah juga dapat dijadikan barang jaminan untuk meminjam uang kepada lembaga keuangan yang memberikan fasilitas kredit. Tanah sangat berharga bagi manusia karena itu tahah sering memicu terjadinya sengketa di masyarakat. Status penguasaan atas tanah harus dilandasi atas hak yang sah sesuai UU No. 5 Tahun 1960 tentang UUPA . UUPA bertujuan yaitu memberikan kepastian hukum berkaitan dengan hak-hak atas tanah bagi masyarakat.

Tanah merupakan bagian yang tak terpisahkan dari hidup dan kehidupan manusia. Sehingga hak atas tanah merupakan hak asasi manusia yang secara hukum berisikan penguasaan dan pemilikan (Rosmidah, 2013). Tanah hak milik merupakan tanah yang paling tinggi statusnya dinegara manapun. Tanah hak milik selain dapat dialihkan juga dapat dibebani hak tanggungan atau dijadikan jaminan dalam pelunasan hutang. Tanah hak milik tidak perlu mendapatkan ijin dari siapa-siapa jika pemiliknya ingin menjadikannya sebagai jaminan untuk meminjang uang dibank. Bank adalah badan usaha penghimpun dana dari masyarakat dalam bentuk simpanan dan menyalurkan dana tersebut dalam bentuk kredit kepada masyarakat. Jaminan kredit yang di terima oleh bank harus dapat diyakini sebagai jaminan yang baik dan berharga sehingga akan dapat memenuhi fungsifungsinya. Fungsi jaminan kredit adalah sebagai pengamanan kredit bila kredit yang diterima pihak peminjam tidak dilunasinya atau wanprestasi sehingga disimpulkan sebagai kredit macet, jaminan kredit yang sebelumnya diterima oleh pihak bank tersebut akan dieksekusi untuk pelunasan kredit macet tersebut. Dengan demikian, Jaminan kredit mempunyai peranan yang sangat penting bagi pengamanan pengembalian dana bank yang disalurkannya kepada pihak peminjam melalui pemberian kredit dengan memperhatikan aspek dari hukum jaminan.

Hal ini dilakukan oleh pihak bank agar bank mendapat kepastian bahwa fasilitas kredit yang diberikan kepada masyarakat dapat dipergunakan sesuai dengan kebutuhan dan dapat kembali dengan aman dan tepat waktu. Namun dalam prakteknya sering menimbulkan kendala dalam hal nasabah bank meninggal dunia kemudian semua kekayaan dan hutangnya dialihkan keahliwarisnya. Kematian seseorang mengakibatkan peralihan atas hak dan kewajiban yang dimiliki pewaris selama hidupnya kepada ahliwarisnya. Segera setelah meninggalnya pewaris ahliwarisnya mengambil alih hak-hak dan kewajibannya. Apabila pewaris pada masa hidupnya memiliki kredit pada bank yang dijaminkan dengan hak tanggungan dan pada waktu meninggalnya pewaris, kredit pada bank itu belum lunas maka akan terjadi peralihan hutang demi hukum kepada ahli warisnya.

Kematian seseorang membawa akibat hukum secara otomatis. Ahli waris berkewajiban melunasi seluruh hutang yang ditinggalkan pewaris. Ahliwaris harus segera mendaftarkan tanah warisannya tersebut kekantor pertanahan agar peralihan hak tanah yang di dapatkan dari warisan tersebut mendapatkan jaminan kepastian hukum.

Berdasarkan hal-hal yang diuraikan tersebut maka rumusan permasalahan yang diambil adalah:

Bagaimana proses pewarisan hak atas tanah yang dibebankan hak tanggungan?

Bagaimana akibat yang dihadapi oleh kreditur terhadap pewarisan hak atas tanah yang dibebankan hak tanggungan?

Tujuan dari penelitian yaitu:

Mengetahui proses pewarisan hak atas tanah yang dibebankan hak tanggungan.

Mengetahui akibat bagi kreditur terhadap pewarisan hak atas tanah yang dibebankan hak tanggungan.

\section{Metode}

Tipe penelitian yang digunakan dalam penelitian hukum ini adalah penelitian hukum normative, Yaitu penelitian hukum ini meneliti bahan pustaka yang sudah ada. Tahapan penelitian hukum normatif adalah penelitian ditunjukan untuk memperoleh hukum objektif, yaitu mengadakan penelitian masalah-masalah hukum. Penelitian juga ditunjuk untuk mendapatkan hukum subjektif. Metode pendekatan masalah digunakan untuk membahas permasalahan penelitian ini adalah melalui pendekatan perundang - undangan dengan pendekatan konseptual.

Sumber bahan hukum yang dipergunakan dalam penulisan skripsi ini yaitu:

Bahan Hukum Primer adalah dilakukan dengan pendekatan dasar hukum yang terkait seperti peraturan UU. Bahan hukum primer yang dapat membantu dan menganalisa dalam penelitian ini berupa peraturan perundang undangan yaitu: 
UUD RI 1945.

KUH Perdata.

UU No. 5 Tahun 1960 tentang UUPA

UU No. 4 Tahun 1996 HakTanggungan.

UU No. 10 Tahun 1998 Perbankan.

Bahan Hukum Sekunder adalah bahan hukum bersumber kepustakaan yaitu berupa literature-literatur, dokumen-dokumen, jurnaljurnal dan artikel-artikel di internet yang ada hubungan mengenai penjelasan permasalahan yang dibahas.

Teknik yang digunakan dalam pengumpulan bahan hukum ini yaitu dengan cara penelitian kepustakaan yaitu dilakukan dengan mencari, mengumpulkan bahan hukum serta mempelajari bahan hukum berkaitan dengan permasalahan yang dibahas. Seluruh bahan hukum yang sudah terkumpul baik primer maupun bahan hukum sekunder selanjutnya dilakukan pengklarifikasi kemudian diolah dan dianalisa dengan menggunakan argumentasi hukum agar dapat menjawab permasalahan yang diajukan. Untuk penyususnan dilakukan secara deskriptif yaitu dengan cara menyusun bahan-bahan hukum yang telah dipilih secara sistematis sehingga membentuk suatu karya ilmiah.

Analisis bahan hukum yang digunakan adalah dengan cara mengumpulkan seluruh bahan hukum primer maupun bahan hukum skunder. Selanjutnya dilakukan klarifikasian, diolah dan dianalisis dengan menggunakan argumentasi hokum agar dapat menjawab permasalahan yang diajukan. Penyusunan penelitian ini dilalukan secara deskriptif atau dengan cara menyusun bahan - bahan hukum yang telah dipilih secara sistematis sehingga membentuk suatu karya ilmiah.

\section{Hasil Penelitian dan Pembahasan}

\section{Peralihan Hak Milik Atas Tanah Karena Pewarisan}

Pewaris adalah orang yang telah meninggal dunia dan meninggalkan seluruh harta kekayaannya baik hutang maupun piutang kepada ahliwarisnya. Ahli waris adalah orang yang berhak atas seluruh harta yang ditinggalkan dari pewaris baik kekayaan maupun hutang pewaris. Hukum waris adalah hukum tentang peralihan atau perpindahan harta kekayaan yang ditinggalkan oleh pewaris kepada ahliwarisnya. Pewarisan hak atas tanah yang dibebankan hak tanggungan harus berlandaskan pada ketentuan UUPA dan peraturan pelaksanaannya. Hak atas tanah dapat dialihkan dan dapat pula beralih.

Boedi Harsono menyatakan, pengertian beralih menunjuk pada berpindahnya Hak Milik kepada pihak lain karena pemiliknya meninggal dunia. Peralihan Hak Milik karena pewarisan terjadi karena hukum, artinya dengan meninggalnya pemilik tanah, maka ahli warisnya memperoleh Hak Miliknya itu menurut hukum sejak ia meninggal dunia (Harsono, 2003). Peralihan hak tanah karena pewarisan itu terjadi karena peristiwa hukum. Selain karena peristiwa hukum hak tanah dapat beralih karena perbuatan hukum yaitu karena pemegang hak tanah dengan sengaja mengalihkan hak tanahnya kepada pihak lain. Peralihan hak tanah kerena pewarisan terjadi akibat pemilik tanah meninggal dunia dan seketika hak atas tanah tersebut beralih kepada ahliwarisnya. Agar hak atas tanah yang diperoleh dari pewarisan tersebut mempunyai kekuatan hukum ahliwaris harus segera mendaftarkan hak tanah tersebut dikantor pertanahan setempat .

Posedur Pendaftaran Peralihan Hak Melalui Pewarisan. Syarat-syarat pendaftaran peralihan hak atas tanah melalui pewarisan adalah syarat materiil dan syarat formal. Syarat Materiil adalah Ahli waris memenuhi syarat sebagai pemegang hak atas tanah warisan tersebut. Syarat Formal adalah ahli waris harus mempunyai surat keterangan mewaris dan surat kematian pewaris. Pendaftaran hak atas tanah yang didapat dari warisan itu penting untuk mendapatkan perlindungan hukum terhadap ahli waris dan juga untuk tertib peraturan pertanahan yang berlaku demi memutakhirkan data fisik dan yuridis administrasi pertanahan. Pendaftaran peralihan hak atas tanah yang terjadi karena pewarisan tidak dipungut biaya dan didaftarkan dalam waktu 6 bulan sejak pewaris meninggal dunia.

Proses pendaftaran peralihan hak tanah karena pewarisan ke Kantor Pertanahan yaitu:

Mendaftarkan

Dilakukan pencatatan

\section{Menyerahkan Sertifikat}

Penerbitan sertifikat hak milik atas tanah merupakan alat bukti yang kuat untuk kepemilikan tanah. Sertifiakat hak milik mempunyai arti yang sangat penting yaitu perlindungan kepastian hukum pemegang hak atas tanah. 


\section{Peralihan Hak Atas Tanah Karena Warisan Yang Di Bebankan Hak Tanggungan}

Peralihan hak atas tanah adalah perpindahan hak atas tanah dari pemegang hak yang lama kepada pemegang hak yang baru. Ada dua macam peralihan hak atas tanah yaitu karna beralih dan karna dialihkan. Beralihnya hak atas tanah tanpa adanya perbuatan hukum yang dilakukan oleh pemiliknya seperti contoh pewarisan hak atas tanah. Sedangkan dialihkan adalah perpindahan hak atas tanah melalui perbuatan hukum yang dilakukan oleh sipemilik hak atas tanah seperti contoh jual beli tanah. Peralihan hak atas tanah karena warisan biasanya didahului dengan membuat surat keterangan hak mewaris. Surat keterangan mewaris dibuat oleh notaris sebagai pejabat yang berwenang. Hambatan yang dihadapi oleh ahliwaris terhadap pewarisan hak atas tanah yang dibebankan hak tanggungan ini yaitu waktu yang dibutuhkan untuk membuat surat keterangan mewaris cukup lama,dan juga biaya yang dikeluarkan untuk membuat surat keterangan mewaris itu. Dasar hukum bahwa hak milik atas tanah dapat diwariskan secara implisit dimuat dalam pasal 10 UU No. 16 Tahun 1985 yaitu Hak milik atas suatu rumah susun sebagaimana dimaksud dalam pasal 8 ayat 3 dapat beralih dengan cara pewarisan atau dengan cara pemindahan hak sesuai dengan ketentuan hukum yang berlaku. Pemindahan hak sebagaimana dimaksud dalam ayat (1) dilakukan dengan akta AHPT dan daftarkan dikantor Kabupaten atau Kota Madya yang bersangkuta menurut PP sebagaimana dimaksud dalam pasal 19 UU No. 5 Tahun 1960.

Hak Tanggungan adalah suatu bentuk jaminan pelunasan hutang dengan hak mendahului dengan objek jaminan berupa hak-hak atas tanah yang diatur dalam UU pokok Agraria. Hak Tanggungan merupakan hak penguasaan atas tanah, memberikan wewenang kepada kreditur untuk menjual atau melelang tanah yang dijadikan barang jaminan untuk pelunasan hutang jika sipeminjam hutang cidera janji atau wanprestasi. Pemberian Hak Tanggungan dilaksanakan dalam 2 tahap yaitu Tahap pertama pemberian hak tanggungan dan Tahap kedua pendaftaran hak tanggungan. Sejak Lahirnya hak tanggungan pemegang hak memperoleh hak yang istimewa yang dikeluarkan oleh UU Hak tanggungan, Kreditur mempunyai kedudukan yang diutamakan. Hak tanggungan juga mengikuti objeknya yaitu kepada tangan siapapun objeknya berada hak tanggungan tetap melekat pada objeknya. Sifat hak tanggungan ini adalah salah satu jaminan khusus bagi kepemilikan hak tanggungan, karena biarpun objek hak tanggungan sudah berpindah tangan dan menjadi milik pihak lain, kreditur masih bisa menggunakan haknya untuk melakukan eksekusi jika debitur wanprestasi. Sertifikat hak tanggungan adalah tanda bukti bahwa hak tanggungan tersebut sudah didaftarkan dikantor pertanahan Nasional. Sertifikat hak tanggungan diserahkan kepada pemegang hak tanggungan.

\section{Akibat Yang Timbul Bagi Kreditur Terhadap Pewarisan Hak Atas Tanah Yang Dibebankan Hak Tanggungan.}

Hak Tanggungan sebagai lembaga jaminan digunakan untuk mengikat jaminan utang yang berupa tanah. Sebagai suatu hak yang bersifat accesoir, lahirnya hak tanggungan didasarkan pada adanya perjanjian pokok atau perjanjian utang-piutang. Perjanjian utang piutang merupakan bagian yang tak terpisahkan dari perjanji yang dituangkan tersebut. Hak tanggungan dapat beralih kepada pihak lain. Pasal 16 dan Pasal 17 undang-undang Hak Tanggungan mengatur tentang peralihan hak tanggungan. Peralihan hak tanggungan bisa terjadi karena cessie, subrogasi, pewarisan, atau sebab lain. Hak tanggungan itu melekat pada objeknya, jika objeknya beralih hak tanggungan itu pun ikut beralih. Beralihnya hak tanggungan yang baru harus didaftarkan pada kantor pertanahan. Hak tanggungan mulai beralih sejak tanggal pencatatan sebagaimana dimaksud pada ayat 4 Pasal 16 dan ayat 5. Pejabat Pembuat Akta Tanah membuat APHT sesuai dengan peraturan perundang-undangan yang berlaku . Kemudian Pejabat Pembuat Akta Tanah (PPAT) melakukan pemberian hak tanggungan melalui Akta Pemberian Hak Tanggungan. Di dalam APHT harus mencantumkan identitas pemberi dan pemegang hak tanggungan dan domisili dari para pihak yang tercantum didalam akta APHT tersebut. APHT yang dibuat oleh pejabat pembuat akta tanah didaftarkan di kantor pertanahan. Dari pendaftaran tersebut akan mendapatkan sertifikat hak tanggungan.

Akibat yang timbul bagi kreditur adalah kreditur harus memberikan kredit baru dimana terlebih dahulu dilakukan dengan penghapusan atau peroyaan hak tanggungan. Setelah diroya hak tanggungan dirubah keatas nama ahliwaris dan didaftarkan kembali. Pendaftaran hak tanggungan merupakan hal yang sangat menentukan lahirnya hak tanggungan. Karena pendaftaran tersebut pihak kreditur mempunyai kedudukan yang istimewa dan diutamakan terhadap pelunasan hutangnya oleh debitur atau 
pihak yang berhutang. Sehingga tujuan APHT dapat tercapai yaitu para pihak bukan saja yang memperjanjikannya akan tetapi pihak lain yang berkepentingan dapat dengan mudah mengetahui secara jelas dan terperinci mengenai adanya pembebannan hak tanggungan yang terjadi sehingga diharapkan tidak akan terjadi perbuatan-perbuatan yang menyimpangi ketentuan perundang-undangan.

\section{Simpulan}

Hak tanggungan tidak akan hapus apabila pemegang hak tersebut meninggal dunia. Hak tanggungan itu akan beralih kepada ahliwarisnya. Proses peralihan hak atas tanah tersebut terjadi karena pewarisan. Pewarisan hak atas tanah terjadi secara yuridis atau secara hukum. Ahliwaris wajib membuat surat keterangan waris dan mendaftarkan warisannya tersebut kekantor pertanahan.

Akibat yang terjadi terhadap pewarisan hak tanah yang dibebankan hak tanggungan yakni Kreditur harus menunggu lama proses balik nama sertifikat hak tanggungan agar menjadi atas nama ahliwaris. Sertifikan hak tanggungan sama kuatnya dengan putusan pengadilan. Tanggal kelahiran hak tanggungan sangat penting bagi kreditur sebagai penentu peringkat hak tanggungan jika ada pemegang hak tanggungan lain atau kreditur lain.

\section{DAFTAR PUSTAKA}

Harsono, B. (2003). Hukum Agraria Indonesia Sejarah Pembentukan Undang Undang Pokok Agraria, Isi, Dan Pelaksanaannya. Jakarta: Djambatan.

Hasanah, U. (2012). Status Kepemilikan Tanah Hasil Konversi Hak Barat Berdasarkan $\mathrm{Uu}$ No. 5 Tahun 1960 Tentang Peraturan Dasar Pokok-Pokok Agraria Dihubungkan Dengan Pp No. 24 Tahun 1997 Tentang Pendaftaran Tanah. Jurnal Ilmu Hukum, 3(1). Retrieved from https://media.neliti.com/media/ publications/9132-ID-status-

kepemilikan-tanah-hasil-konversi-hakbarat-berdasarkan-uu-no-5-tahun1960.pdf

Novita, C. F. (2014). Tinjauan Hukum Terhadap Jual Beli Tanah Tanpa Akta PPAT (Wilayah Kecamatan Tinombo). Jurnal Ilmu Hukum Legal Opinion, 3 (2). Retrieved from https:// media.neliti.com/media/ publications/152126-ID-none.pdf
Rosmidah, R. (2013). Kepemilikan Hak Atas Tanah di Indonesia. INOV A TIF: Jurnal Ilmu Hukum, 6(2). Retrieved from https://online-journal.unja.ac.id/ index.php/jimih/article/view/2118 